\title{
Towards identifying choice (strategies) of technologies vs vagaries on coconut for sustainable adoption - A field - oriented exercise in participatory planning and action
}

\author{
B. Subburaj ${ }^{1}$ and R. Subramanian ${ }^{2}$
}

\begin{abstract}
Promotion of greater access to affordable choice of technologies and their prompt use for coconut productivity is necessary to sustainable development of coconut farming. The crux of the issue is; coconut growers who are aware and have the knowledge of the technologies, also seem to be reticent about adopting the package. The question therefore is; why does this happen? This research paper summons the identification of social and ecological elements that surround adoption of innovative technologies in improving coconut production and the kind of strategies for a best fit for a need-based programme of knowledge transfer, facilitating picking up a few technologies for possible adoption. A methodological prime-mover viz., Participatory Rural Appraisal, Planning and Action among coconut growers was used to walk the 'reality-led' and 'technology-driven' choices that are really acceptable and usable. Yet the farmers/neighbours appeared to be reluctant even to "talk" the "walk". On the other hand, absence of dependable and sustainable model, lack of confidence, inadequate infrastructure and support systems, including sufficient and timely credit and constant exposure through IT seem to accelerate 'vagaries' on coconut for sustainable adoption. The need must, therefore be to polarize the two contrasting positions-appropriate tech-choice vs vagaries of adoption-by a suitable 'model' that would serve as a guide to coconut farmers.
\end{abstract}

\footnotetext{
${ }^{1}$ Professor of Cooperation and ${ }^{2}$ Former Professor in the Department of Applied Research and Dean, Faculty of Rural Development at Gandhigram Rural Institute - Deemed University, Gandhigram, Tamilnadu, India.
} 


\section{Introduction}

Throughout India coconut palm is eulogized as Kalpavriksha or the 'tree of heaven' and its fruit as Lakshmiphal, the fruit of wealth. It is grown in 1.84 million ha and nearly 12,259 million nuts are produced accounting for 22.36 percentage share to world production (APCC, 2000; CDB, 2003). The crop supports 10 million people and contributes US \$ 1458.3 million to the GDP and US \$ 71.04 million to the foreign exchange earnings (Coir Board, 2002). However, compared to other countries where coconut is grown, for instance Mexico and Sri Lanka where the overall productivity is 11,727 and 7,005 , respectively, it is 6,891 nuts per ha per year in India (APCC, 2000). Alongside, spatial differences and variations in productivity of coconut have also been observed. For instance, Tamilnadu has recorded the highest productivity $(10,599$ nuts per ha per annum) while it is 5,870 nuts per ha per annum in Kerala (CDB, 2003). Further, in the case of Tamilnadu even though the overall productivity is 10,599 nuts, there are vast locational variations in the productivity of coconut among important coconut growing districts. For example, while East Tamilnadu (Thanjavur region), holds up a productivity of 15,522 nuts per ha. It is only 10,693 nuts per ha. in North Tamilnadu (Kanchipuram region). Likewise, the productivity is 14,072 nuts in East coastal regions whereas it is 15,537 nuts in western ghats regions in Tamilnadu (Govt. of Tamilnadu, 2001).

Thus, while locational productivity differentials can be attributed to several factors, the non-adoption of appropriate onfarm productivity increasing technologies per $s e$ is regarded as the major cause for low productivity and its variance in the country (Thampan, 1988; Bavappa, 1990; Nampoothiri, 1998; Iyer and Nambiar, 1998; Subburaj, 2000; Singh, 2002; Ratnambal et al., 2003).

Further, the prevailing notion across the country is that non-adoption of improved cultural technologies on coconut is due to lack of knowledge and understanding of the improved cultural technologies on the part of coconut growers; though imperfections in the marketing systems for coconut, lack of bargaining and staying power among coconut growers, tenuous institutional arrangements and support for technology transfer, inadequate infrastructural facilities and services, etc. (GOI, 1999) also contribute in no small measure towards nonadoption of technologies on coconuts.

Bavappa et al. (1976), Nair et al. (1996), Nampoothiri (1998), Ohler (1999), Nampoothiri and Singh (2000), Singh (2002), and Ratnambal et al. (2003) claim that research and extension on coconut development has produced only a feeble impact on the palm yield, probably due to a mosaic of adoption practices. Although farmers seem to know the substantial economic and social benefits that go usually with the adoption of new technologies (Harrison, 1994), significant differences in the adoption are observed among marginal, small, medium and big coconut growers. The level of knowledge about cultural technologies has seldom been uniform among coconut growers, on the other hand, it varied from place to place and amongst growers. For instance, coconut growers in coastal regions and specifically in dense coconut population areas, as well as commercial and big coconut growers in Tamilnadu have a higher level of knowledge on improved coconut farming practices than small coconut growers (who have less number of palms) who are on recommended package of practices of coconut (Yogananda et al., 1994), and who demonstrate more knowledge about traditional coconut farming practices (Kalavathi and Anithakumari, 1998). In spite of their knowledge of the recommended practices on coconut cultivation, the coconut growers, particularly in the western ghats region, fell short of pest and disease control technologies (Saravanan, 2000), whereas, farmers who availed of the services of government and development research institutions seemed to be more knowledgeable (Chandra Bindu, 1995).

Thus, the linkage of coconut productivity to knowledge of changing technologies and their use can be said to be inviolate. So, the guide post to productivity is to ease transfer of technologies to coconut farms in a manner that could bring the hitherto fragmented practices in technology application into convergence; for, 
coconut production is intricated, is embedded in its coconut palm culture and coconut palm culture is embedded in larger techno-options that need to be defined by the choice of sustainable adoption strategies. Against this background, an attempt has been made in this paper to help ensure (i) designing etc., and execution of strategies as acceptable and usable practices on the farm, and (ii) cognitive adoption and critical evaluation of the practices in terms of individual situations (Ramsey et al., 1959; Rogers, 1983), with a slant on substantial economic and social benefits (Harrison, 1994).

\section{Approach}

A few experiments in developing countries have proved the relevance and effectiveness of 'group approach through micro-institutional' framework in addressing common problems of a community (Adams and Graham, 1984). Such micro-institutions have facilitated participatory planning and action in tandem to the overall social, economic and cultural framework of a society/community (World Bank, 2001). The experience already gained also indicated that institutionalization of group efforts by conferring corporate existence to the mission and objectives of the group through self-governance, would work. Applied to coconut culture, therefore, the following steps were designed for effective demonstration and sustainable adoption of the technologies through participatory means.

* Understanding the demographic, social, economic and coconut farming indicators including the existing stock of knowledge of technologies on coconuts, and the factors influencing the adoption of productivity increasing technologies on coconuts of coconut growers facilitating the identification and selection of target segments of coconut growers and, formation and promotion of self-help societies.

* Enlightenment and empowerment of members of the self help societies through self-governance and participatory action.

* Participatory appraisal of the practices and problems in the adoption of cultural technologies on coconuts of members of self help societies through participatory learning.

* Participatory micro-planning and execution, including monitoring the pattern and extent of adoption of technologies on coconuts.

* Execution of need-based knowledge support schemes for transfer of technologies on coconut farms.

* Identification of the problems and barriers and their analysis in the matter of adoption of technologies on coconuts so as to facilitate redesigning and execution of appropriate strategies through self help societies among growers.

\section{Identification of coconut growers}

Formation and promotion of self help societies among coconut growers call for identification and selection of the core audience of coconut growers with the following traits:

* The coconut growers who could appreciate and atleast aim at adoption of technologies on coconuts,

* The coconut growers who maintain high neighbourliness and leadership qualities ( that are very much essential for group formation and organizational development), and

* The coconut growers who could contribute to the business viability of their self help societies.

Therefore, in order to identify coconut growers with the above traits (core audience) in the project villages, a mixture of methods viz., field survey, focus-group discussions and socio-metric analysis was employed. As a result, a group of coconut growers comprising 15-20 individuals was identified in each of the project villages whom where the preliminary step for the 'concept selling' had been carried out by establishing good rapport through several individual and group meets. 


\section{Formation of self help societies by participatory appraisal}

The core audience as identified through intermixing of methods were sensitized to the concept of self help societies (SHS) which are micro-organizations with a legal base and corporate existence. The very concept of such micro institutions was put across through focusdiscussions with emphasis on their locationspecific significance and objectives. This provided the opportunity to identify members for the core audience comprising those convinced of the need and significance of self help societies in addressing their production and marketing problems. Over several such meets of core

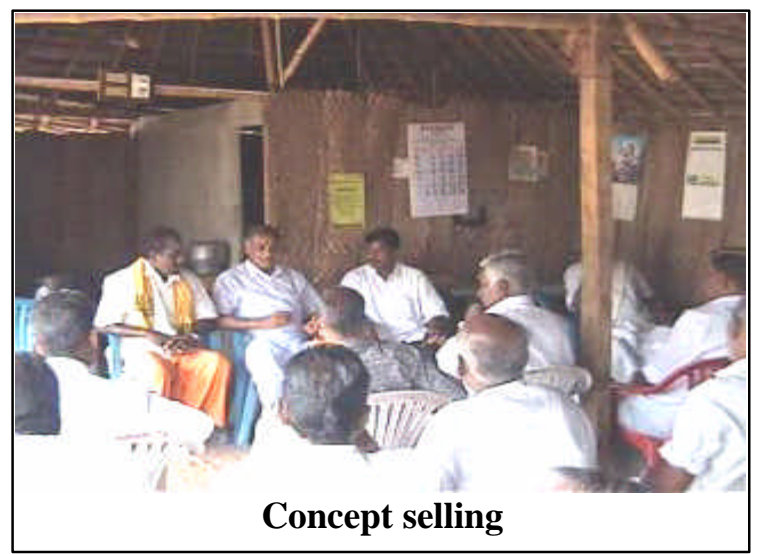

audience, the appropriate guidelines for identification, selection and admission of coconut growers into the self help society membership, as well as the management and administration, ways and means of resource mobilization, designing of operational procedures, code of conduct, and the relating to self help society rules etc., in tandem to the statutory provisions (Societies Registration Act 1975 and rules 1978, Tamilnadu) were evolved. As the core audience was very keen on the quality considerations of individuals, they expected lesser number of coconut growers in each group-not exceeding 20-25 in their locale.

Steps were initiated for institutionalization of the associationship of members of core audience by getting them registered under the Tamilnadu Societies Registration Act 1975. Such registered groups are called the Self Help Societies. The leaders of each

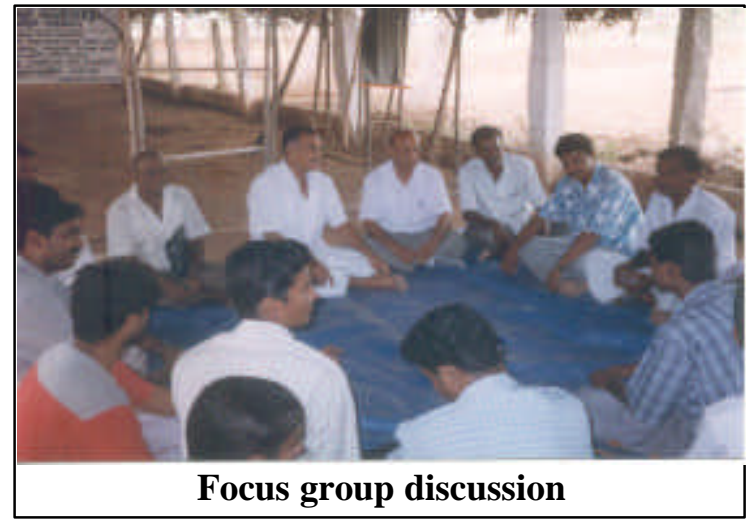

society were propelled and guided to take up activities pertaining to strengthening their self help societies through 'expulsion as well as admission' of individuals into the membership.

The leaders have convened special and general meetings and committee meetings frequently as part of their organizational development and management. All this, they were told, was necessary for an active head-start. Eventually they got themselves initiated (self motivated) to making (the concept of 'sarvodaya democracy') 'decisions by consensus of all' instead by the majority'. Attempts were made to promote 12 self help societies among coconut growers. However only 10 of them proved themselves to be genuinely motivated to carry out the activities falling within the objectives of their 'association-ship'; therefore, these caught the eye and so were picked up for furtherance and promotion.

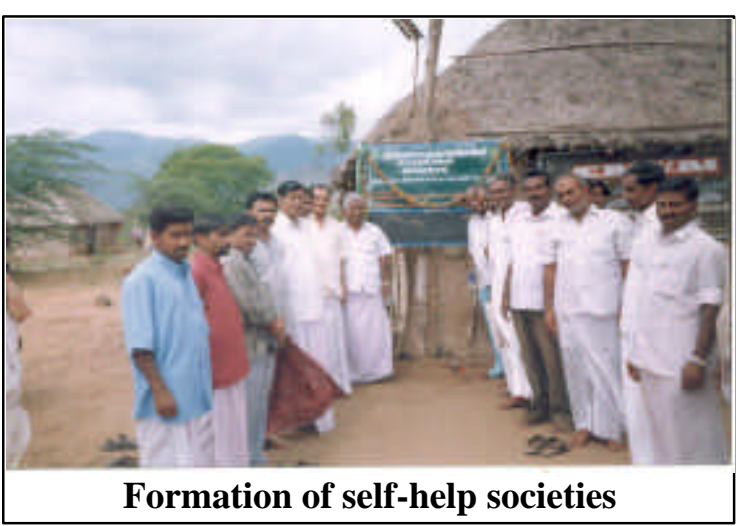




\section{Knowledge transfer schemes}

The inferences from PRA exercise and the administering of a short survey as applied to members of self help societies uncovered problems impinging on the adoption of cultural practices; they provided a guidepost to the kind of strategies to (be adopted by means of) fashion designing and execution of an appropriate 'need based programmes' for knowledge transfer of cultural technologies on coconuts, and initiating measures towards strengthening the capability of self help societies in addressing the economic problems of members as well. Accordingly, a few training programmes on on-farming productivity increasing technologies in consonance with the needs and requirements of coconut growers were spelt out for the benefit of all members of the self help societies. Experts from Agricultural Research Institutions, NGOs, freelancers and adopters of cultural technologies

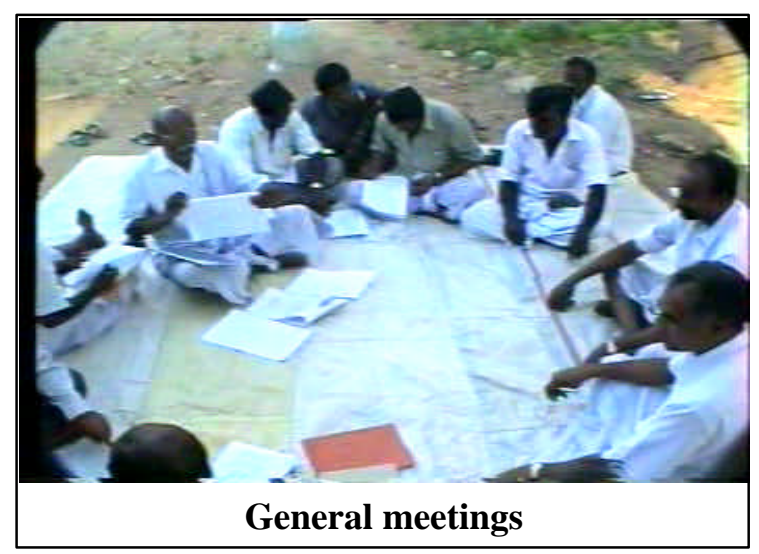

on coconuts were invited to actively participate and deliver the goods. Field exposure visits were also arranged. Class room discussions were combined with on-farm; demonstrations field visits were also organized. More specifically, the coconut growers were exposed to information and knowledge about relevant technologies on soil fertility management, water and drought management, vermi and coir pith compost, organic recycling and enriched farm yard manuring, integrated pest and disease control, mixed cropping and bee-keeping in coconut gardens. Furthermore, this was strengthened by providing each society with flex print photographs, handouts and brochures, depicting
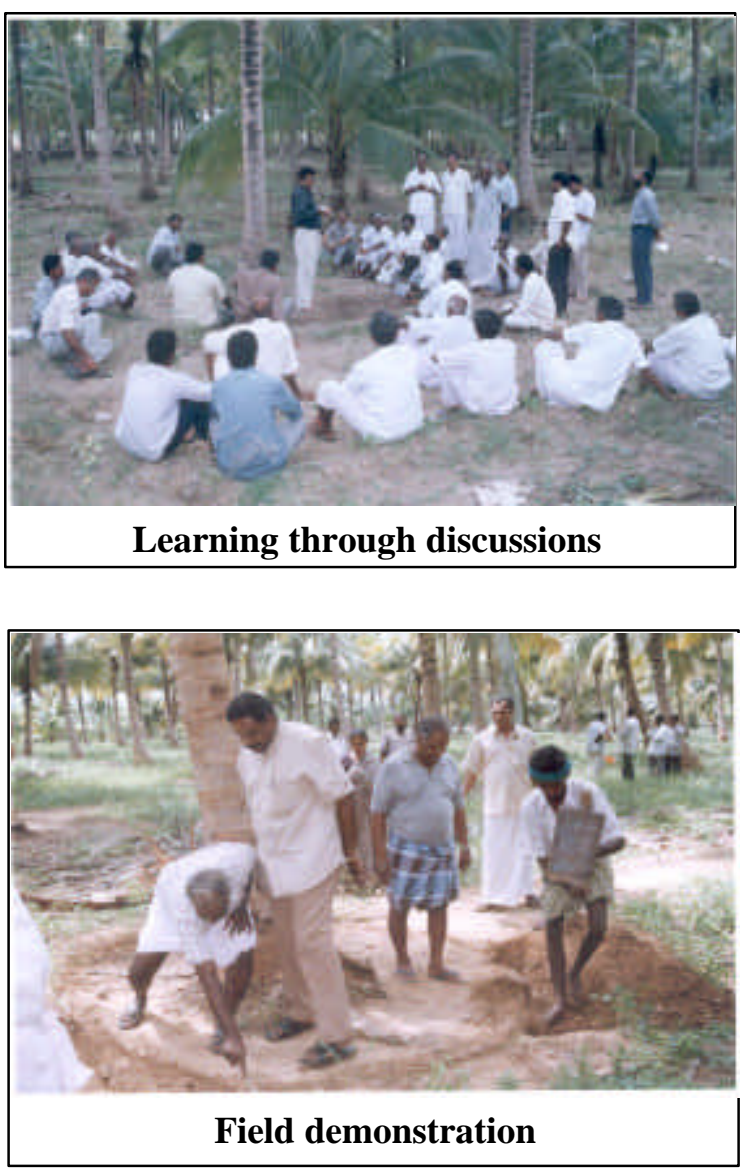

the methods and result demonstrations of technologies for their adoption.

\section{Participatory micro planning and execution}

Following the programmes of knowledge transfer to members of self help societies with the objective of enlightening and inculcating each member on the relevance and urgency of the technologies for farm application, the next step was to help prepare, micro-plans for adoption. The members of the society were oriented to determine their choice of technologies, with a thrust on adoption of onfarming productivity increasing technologies in the context of 'establishing 'zero cost coconut cultivation' keeping in mind the following broad guidelines.

* Adoption of scientific methods for in situ moisture maintenance and irrigation management, 
* Adoption of organic farming and gradual withdrawal from inorganic farming practices,

* Intercropping in coconut gardens, and

* Adoption of integrated coconut farming system.

Accordingly, members identified and picked a few technologies for adoption, keeping in view their micro environment, comprising soil type, adequacy and dependability of irrigation sources, access to facilities including resources at their disposal and the felt need and urgency of the situation perceived by them. They were also encouraged promptly to adopt their opted technologies within a time span of six months immediately following the North-East monsoons that burst annually from September to November. Finally, the executive members of each society were guided to knit a
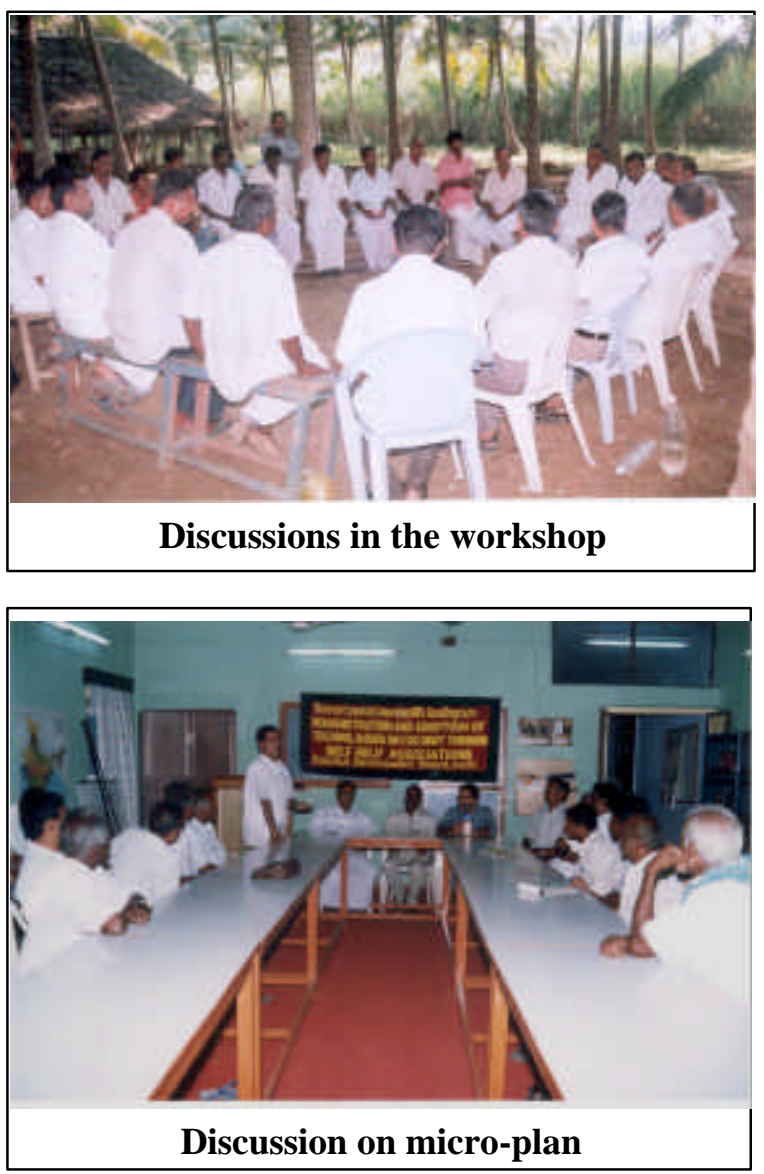

comprehensive detailed micro plan from the individual plans of their members for an orderly execution and monitoring among the fellow members. They were motivated to guide, counsel and review the performance of each member with respect to adoption of technologies by holding frequent review meetings and focus group discussions. Eventually (it was observed) they were able to find the right type of actions and solutions for a few common problems through their self help society.

\section{Cognitive adoption and review results}

Table 1 depicts details of the adoption of on-farming productivity increasing technologies by members of self help societies during a time span of 12 months from August to July (200304). The number of cases (members of coconut growers self help societies) was 194; they were grouped under four different categories namely innovators, early adopters, early majority, and late adopters based on their adoptability and adoption of technologies on coconuts within the stipulated timeframe.

It is evident from the Table 1 that none of the members (coconut growers) adopted the entire 5-piece package of practices of the cultural technologies on coconuts. Yet our experiment showed 51.86 percentages of the cases under the "adopters" category, non withstanding the non-adoption of the entire package of practices on cultural technologies on coconut. A majority of them belonged to 'partial adopters' because they could identify the choice of one or more of the package of practices depending on the urgency of the technology suitable to their farm and its operational situation.

\section{Critical review}

The performance of the 'innovative' group of farmers failed to attract neighbouring farmers. The 'nibblers' in particular were conspicuous by their noticeable absence. They were mere spectators and observers. Reason frequently quoted for this was that the farmers under the 'innovator category' were not able to show significant addition / increase in their 'economic 
gains' from their palms on account of the adoption of one or more of the cultural technologies on coconuts. Moreover, even a little amount of additional increase in the palmincome of the innovators was attributed to locational differences and differences / variation in soil and water resources of their farms. At the same time, cases of farmers owning palms on fertile soil including dependable source of irrigation, but without applying improved technologies were widely referred to and loudly deliberated. Besides, the 'innovative' attempts by the 'innovative category' among the farmers in villages were rendered more or less futile as a result of absence of dependable model for replication.

Furthermore, fellow farmers showed scanty acknowledgement and acceptance of the efforts of the 'innovative' farmers for the simple reason that the former did not perceive the forays of the latter as something 'new' based on their experience and awareness of most of the technologies on soil fertility, drought / water management and integrated farming in coconut farms. On the other hand, if the farmers under innovator category who used vermi / coir pith compost as a measure for increasing the soil fertility and insitu moisture maintenance in their coconut farms, probably were appreciated out of curiosity as something 'new' by the fellow farmers. At the same time, the fellow farmers looked down upon mulching of the farm wastes in the palm basin, as that would invite the perilous reptiles in search of their prey and evil beetles much to their dislike. Side by side they also did not discountenance a little income that the sale of palms waste would offer. The palm leaves, the midribs and the flower sheath, etc., would fetch much income.

As for inter-ploughing and, farm and palm cleaning, it was observed that the fellow farmers inter-ploughed atleast thrice annually; weeded atleast once in a month and palm cleaning during every harvest of coconuts at an interval of 45 50 days. Since these practices were routine, the fellow farmers did not consider such activities as 'innovative'. On inquiry, they said that keeping the farm free from weeds has been considered to be the most important explicit indicator of the financial liquidity condition of the farm owner. A farmer who did not keep the farm free from weeds sent a negative message about his financial stability - a sort of penurious living. As for palm cleaning, tree climbers seemed to have the upper hand.

As for intercropping, the farmers seemed to have switched over to coconut cultivation as a means to check the escalating cost of cultivation particularly the cost of farm labour incurred in raising short duration/seasonal crops. Therefore, coconut growers, who knew something about intercropping in coconut gardens, turned a blind eye to such technologies. Adoption of integrated farming appeared to have lost luster among coconut growers, only a less percentage (ranging from 2 to $8 \%$ ) has been rearing milch animals, goat, sheep, etc. Moreover decisions on the adoption of intercropping and integrated farming were mostly made by women of the coconut farming household since rearing animals and looking after them including the farm constituted their portfolio.

\section{Conclusion}

In a true sense coconut growers who adopted the technologies can not be claimed as 'innovators' because they adopted one or two of the technologies pertaining either to soil fertility management or to water / drought management or plant protection or the like. Moreover, results of 'innovative' performance on the farm were blocked by variations in location as well as in soil fertility, use of irrigation facilities rather than on the prime mover - 'innovative' technology as these were a matter of routine farm exercise. So they were reticent about innovative adoption. None seemed to have adopted the entire package of practices of the technologies on coconuts. Moreover, most of them appeared to have adopted the technologies with reservation because of their gestation period though with strong reasons; their reason too has a social veil around them; they reached out to adopt a couple of the technologies as a strategy to tide over a crisis situation caused by nature or to harness 
Table 1. Adoption of on-farming productivity increasing technologies on coconut

\begin{tabular}{|c|c|c|c|c|c|}
\hline \multirow{2}{*}{ Technology adopted } & \multicolumn{5}{|c|}{ Distribution of farmers $(\mathrm{N}=194)$} \\
\hline & Innovators & $\begin{array}{c}\text { Early } \\
\text { adopters }\end{array}$ & $\begin{array}{c}\text { Early } \\
\text { majority }\end{array}$ & $\begin{array}{c}\text { Non } \\
\text { adopters }\end{array}$ & Total \\
\hline \multirow{2}{*}{$\begin{array}{l}\text { Soil fertility management } \\
\text { • Application of FYM }\end{array}$} & & & & & \\
\hline & $\begin{array}{c}20 \\
(10.31)\end{array}$ & $\begin{array}{c}45 \\
(23.20)\end{array}$ & $\begin{array}{c}35 \\
(18.04)\end{array}$ & $\begin{array}{c}94 \\
(48.45)\end{array}$ & $\begin{array}{c}194 \\
(100)\end{array}$ \\
\hline $\begin{array}{l}\text { - Application of green } \\
\text { manure } \\
\text { - Raising cover crops }\end{array}$ & $\begin{array}{c}72 \\
(3711)\end{array}$ & $\begin{array}{c}98 \\
(50.52)\end{array}$ & $\begin{array}{c}24 \\
(1237)\end{array}$ & ---- & $\begin{array}{c}194 \\
(100)\end{array}$ \\
\hline & $\begin{array}{c}27 \\
(13.92)\end{array}$ & $\begin{array}{c}20 \\
(10.31)\end{array}$ & --- & $\begin{array}{c}147 \\
(57.77)\end{array}$ & $\begin{array}{c}194 \\
(100)\end{array}$ \\
\hline - Application of NPK & $\begin{array}{c}99 \\
(51.03)\end{array}$ & $\begin{array}{c}40 \\
(200.61)\end{array}$ & $\begin{array}{c}10 \\
(5.15)\end{array}$ & $\begin{array}{c}45 \\
(23.20)\end{array}$ & $\begin{array}{c}194 \\
(100)\end{array}$ \\
\hline $\begin{array}{l}\text { - Application of vermi- } \\
\text { compost }\end{array}$ & ---- & $\begin{array}{c}15 \\
(7.73)\end{array}$ & ---- & $\begin{array}{c}179 \\
(92.27)\end{array}$ & $\begin{array}{c}194 \\
(100)\end{array}$ \\
\hline $\begin{array}{l}\text { - Application of coir pith } \\
\text { compost }\end{array}$ & ---- & $\begin{array}{c}35 \\
(18.04)\end{array}$ & ---- & $\begin{array}{c}159 \\
(81.96)\end{array}$ & $\begin{array}{c}194 \\
(100)\end{array}$ \\
\hline \multirow{2}{*}{$\begin{array}{l}\text { Water / drought management } \\
\text { - Basin / trench irrigation }\end{array}$} & & & & & \\
\hline & $\begin{array}{c}38 \\
(19.59)\end{array}$ & $\begin{array}{c}156 \\
(80.41)\end{array}$ & ---- & --- & $\begin{array}{c}194 \\
(100)\end{array}$ \\
\hline - Non-inter ploughing & $\begin{array}{c}28 \\
(14.43)\end{array}$ & $\begin{array}{c}110 \\
(56.70)\end{array}$ & $\begin{array}{c}56 \\
(28.87)\end{array}$ & --- & $\begin{array}{c}194 \\
(100)\end{array}$ \\
\hline $\begin{array}{l}\text { - Mulching in the palm } \\
\text { basins }\end{array}$ & $\begin{array}{c}27 \\
(13.92)\end{array}$ & $\begin{array}{c}110 \\
(56.70)\end{array}$ & $\begin{array}{c}48 \\
(24.74) \\
\end{array}$ & $\begin{array}{c}9 \\
(4.64) \\
\end{array}$ & $\begin{array}{c}194 \\
(100) \\
\end{array}$ \\
\hline \multicolumn{6}{|l|}{ Plant protection } \\
\hline - Application of neem cake & --- & $\begin{array}{c}100 \\
(51.54)\end{array}$ & $\begin{array}{c}10 \\
(5.15)\end{array}$ & $\begin{array}{c}84 \\
(43.31)\end{array}$ & $\begin{array}{c}194 \\
(100)\end{array}$ \\
\hline - Palm and weed cleaning & $\begin{array}{c}129 \\
(66.50) \\
\end{array}$ & $\begin{array}{c}50 \\
(25.77) \\
\end{array}$ & ---- & $\begin{array}{c}15 \\
(7.73) \\
\end{array}$ & $\begin{array}{c}194 \\
(100) \\
\end{array}$ \\
\hline \multicolumn{6}{|l|}{ Inter-cropping } \\
\hline - Fodder crop raising & $\begin{array}{c}38 \\
(19.59)\end{array}$ & $\begin{array}{c}15 \\
(7.73)\end{array}$ & --- & $\begin{array}{c}141 \\
(72.68)\end{array}$ & $\begin{array}{c}194 \\
(100)\end{array}$ \\
\hline - Other crops & $\begin{array}{c}13 \\
(6.70) \\
\end{array}$ & $\begin{array}{c}67 \\
(34.54) \\
\end{array}$ & ---- & $\begin{array}{c}114 \\
(58.77) \\
\end{array}$ & $\begin{array}{c}194 \\
(100) \\
\end{array}$ \\
\hline \multicolumn{6}{|l|}{ Integrated farming } \\
\hline • Dairying & $\begin{array}{c}15 \\
(7.73)\end{array}$ & $\begin{array}{c}10 \\
(5.15)\end{array}$ & --- & $\begin{array}{c}169 \\
(87.12)\end{array}$ & $\begin{array}{c}194 \\
(100)\end{array}$ \\
\hline - Goat / sheep rearing & $\begin{array}{c}5 \\
(2.85)\end{array}$ & $\begin{array}{c}5 \\
(2.58)\end{array}$ & ---- & $\begin{array}{c}184 \\
(94.84)\end{array}$ & $\begin{array}{c}194 \\
(100)\end{array}$ \\
\hline - Bee-keeping & ---- & $\begin{array}{c}40 \\
(20.61)\end{array}$ & ---- & $\begin{array}{c}154 \\
(79.39)\end{array}$ & $\begin{array}{c}194 \\
(100)\end{array}$ \\
\hline Total (average) & $\begin{array}{c}32 \\
(16.46)\end{array}$ & $\begin{array}{c}58 \\
(29.51)\end{array}$ & $\begin{array}{c}11 \\
(5.89)\end{array}$ & $\begin{array}{c}93 \\
(48.14)\end{array}$ & $\begin{array}{c}194 \\
(100)\end{array}$ \\
\hline
\end{tabular}

Figures in brackets are percentages to row total 
technologies an instant for quid proquo. Similarly a few had adopted raising cover crops in their coconut gardens when the seeds were supplied under the scheme of the Government, free of cost or at a subsidized price, and discontinued its adoption latter; on top of these the lack of a model, dependable and sustainable, to rule the roost. There is a dire need to build up a framework for choice of technologies to serve adoption for sustainable coconut productivity.

Probably the coconut growers suffered from want of adequate infra-structure prop, including sufficient and timely credit and constant exposure, through IT, to the concept and field practices of updated technologies on coconut. In this connection, the creation of a 'Sustainable Adoption - Tech Watch' (SATW) among the identified innovators and non-adopters may be a practical strategy that could be posed through the unstinted financial support and alertness of the self help societies, which could be a multipurpose centre for dissemination of knowledge and information spread and efficient resource use as well. In due course probably the 'vagaries' in the adoption of new technologies will yield place to value added cocotechnologies.

\section{Acknowledgement}

The authors acknowledge the Coconut Development Board, GOI, Kochi, India for its financial support in taking up the research on 'Demonstration and Adoption of Technologies on Coconut'.

\section{References}

Adams Dale, M. and Graham, D.H. 1984. A Critique of Traditional Agricultural Credit Policies: in Agricultural Development in Third World, C. Eicher and J.M. Staatz (Eds.). Baltimore: John Hopkins University press.

APCC, 2000. Statistical Year Book, Jakarta: Indonesia, $269 \mathrm{pp}$.

Bavappa, K.V.A. 1976. CPCRI and Coconut Research, Indian Farming 26(9).
Bavappa, K.V.A. 1990. Management of coconut based farming system. Proceedings of the COCOTECH Meeting on Coconut Based Farming Systems, Hochiminh City, Vietnam: FAO.

Chandra Bindu, K.R. 1995. An empirical analysis on homestead farming. Tamilnadu Agricultural University Coimbatore (unpublished thesis).

Coconut Development Board, 2003. Coconut Statistics (Supplement), P. Rethinam and T.B. Nandakumar. (Eds.). Kochi, India.

Coir Board, 2002. Annual Report, Kochi, India.

GOI, 1999. Report on Participatory Appraisal of Marketing of Coconuts: Practices and Problems in Tamilnadu, New Delhi: Ministry of Agriculture and Cooperation.

Government of Tamilnadu, 2001. Department of Economics and Statistics, Chennai.

Harrison Steve, R. 1994. Technology adoption in rural development - The case of non adopters with special reference to credit. In: Technological Change and Rural Development in Poor Countries - Neglected Issues. C. Roy Karthick and Cal. Clark, (Eds.). Oxford University, Calcutta.

Iyer, R. and Nambiar, K.K.K. 1998. Integrated disease management in coconut. Indian Cocon. J. 29(4): 90-94.

Kalavathi, S. and Anithakumari, P. 1998. Level of knowledge of coconut growers and level of adoption of technologies. Tree World Vol. 7, No. 9, 4 pp.

Nair, M.K., Ratnambal, M.J. and Gopalasundaram, P. 1996. Coconut research in India, pp. 181-198. In: Coconut for Prosperity. Thampan (Ed.). CPCRI, Kasargod, 274 pp.

Nampoothiri, K.U.K and Singh, H.P. 2000. Trends in Coconut Research and Development in India, CDB, Kochi, India. 
Nampoothiri K.U.K. 1998. Milestones in Coconut Research, Indian Cocon. J., May.

Ohler John, G. 1999. The coconut palm and its environment - Historical background. In Modern Coconut Management - Palm Cultivation and Products, FAO of UN, New Delhi, India.

Ramsey C.H., et al. 1959. Values and adoption of practices. Rural Sociology, New Delhi, 24.

Ratnambal, M.J., Arunachalam, V. and Krishnan, M. 2003. Floral biology of some coconut accessions, J. Plant. Crops, 31(1): 14-22.

Rogers Everett, M. 1983. Diffusion of Innovations $\left(3^{\text {rd }}\right.$ ed.). The Free Press, New York.

Saravanan, M.P. 2000. Spread and acceptance of critical coconut production technology, Agricultural College and Research Institute, Madurai, Tamilnadu Agricultural University, (unpublished thesis).
Singh, H.P. 2002. Strategic agenda for improving competitiveness of coconut industry in the midst of challenges from competing product. Paper presented in XXXIX Cocotech, Thailand.

Singh, K. 2000. Technology Adoption and Agricultural Productivity, Indian $J$. Agricul. Econ. 55(3).

Subburaj, B. 2000. Coconut Marketing in Tamil Nadu, Ministry of Rural Areas and Employment, Department of Rural Development, GOI, New Delhi.

Sudha, M. and Reddy, V.V.R. 1987. Economics of coconut cultivation. Indian Cocon. J. 18(7): 20-21.

Thampan, P.K. 1988. Glimpses of Coconut Industry in India. CDB, Kochi.

World Bank, 2001. World Development Report - 2000/01, Washington DC.

Yogananda H.G., et al. 1994. Knowledge Level of Coconut Growers. J. Ext. Edu. 5(3). 